\title{
English Teaching and the Cultivation of Young People's Cultural Confidence
}

\author{
Aimei Yang \\ Wenzhou Vocational \& Technical College, Wenzhou, China \\ 334710101@qq.com
}

Keywords: English teaching, Young people, Cultural confidence

\begin{abstract}
In order to deeply study the cultivation of young people's cultural self-confidence in English teaching. Through the investigation and analysis of the status quo affecting young people's cultural self-confidence, the relevant reasons are found out. Methods and measures to develop students' self-confidence in English teaching have been proposed. To improve young people's cultural self-confidence, teachers need to take the following methods: cultivate harmonious teacher and student emotions and stimulate young people's interest in learning; correctly treating young people's mistakes; use motivational language in class; formulate level educational goals and implement tiered teaching; use formative evaluation; implement hope and success education. By comparing the two classes with horizontal and vertical two self-confidence measurement scales, it is concluded that the teacher's teaching behavior is positively related to the students' self-confidence.
\end{abstract}

\section{Introduction}

Cultural self-confidence is a strong recognition and pride of the nation, the country and the political party on its own cultural values; cultural self-confidence is the core force to deal with the impact and erosion of foreign culture (Tucker \& George, 2016). With the accelerating process of economic globalization, the conflicts between the world's multiculturalism have become more and more fierce (Ellis, 2016). The cultural influences and value belief systems intertwined by different cultural groups have continually impacted China's mainstream values (O’Shea, 2016). It has a firm belief in its own cultural vitality and grasps the cultural development prospects from development practice; with the expansion of the Internet and multimedia technologies, a new round of cultural shocks will bring new challenges to China's cultural security and ideological security (Hayes \& Mansour, 2016). Cultural self-confidence is the core strength to identify the strengths and weaknesses of culture and respond to cultural shocks (Forbes \& Skamp, 2016). Only by accurately grasping the nature of society and the stage and orientation of social development, grasping the characteristics of the times in which they live, and taking this as the starting point for thinking about problems, starting from the reality and specific conditions and environment, choosing the cultural concept to meet the current practical requirements, the multicultural infiltration and erosion can be dealt with (Gutiérrez \& Larson, 2017). It is also a reasonable sublation of its own culture and foreign culture. It can be concluded that cultural self-confidence is essentially a value orientation (Peng, Chahine \& Husein, 2017). Cultural self-confidence is the inevitable action of the great 
development and prosperity of culture (Sewell, 2017). Adherence to the socialist culture with Chinese characteristics is to achieve cultural self-reliance and self-improvement and lay a realistic foundation for the construction of a cultural power. The prosperity and development of culture can't be separated from the firmness and enhancement of the self-confidence of national culture (Sewell, 2017).

For a long time, English teaching has focused on language skills training and knowledge transfer and has paid insufficient attention to the cultivation of cultural self-confidence. On the other hand, the theory of cultural self-confidence is multi-dimensional, and empirical research methods are lacking (Bartlett \& Mendenhall, 2017). In the actual teaching, there is no framework for cultivating cultural self-confidence that is suitable for Chinese English teaching practice and has high recognition and high operability (Thomas \& Warren, 2017). All these have affected the effect and quality of cultivating cultural confidence in English teaching (Warren, 2018). The concept and connotation of cultural self-confidence ability are sorted out, the relationship between English language teaching and cultural self-confidence ability training is explored, and the way to cultivate cultural self-confidence in English teaching practice is discussed so that English teaching can better meet the needs of the times of national, social and talent training (Serpell, 2017).

\section{Methodology}

\subsection{Research object}

This survey selects students from two classes of junior high school in Yucai Middle School of Economic Development Zone in Chongqing as the experimental subjects. The number of students in the two classes is the same, and there is no difference in the entrance results. Class 1 is the experimental class and Class 2 is the control class.

\subsection{Investigation time}

From September 2017 to January 2018, a total of 4 months.

\subsection{Research framework and theoretical basis}

This study constructs a theoretical framework that combines the "three-dimensional literacy model", "e-learning environment" and "action learning theory" to cultivate the cultural self-confidence ability of English majors (Figure 1).

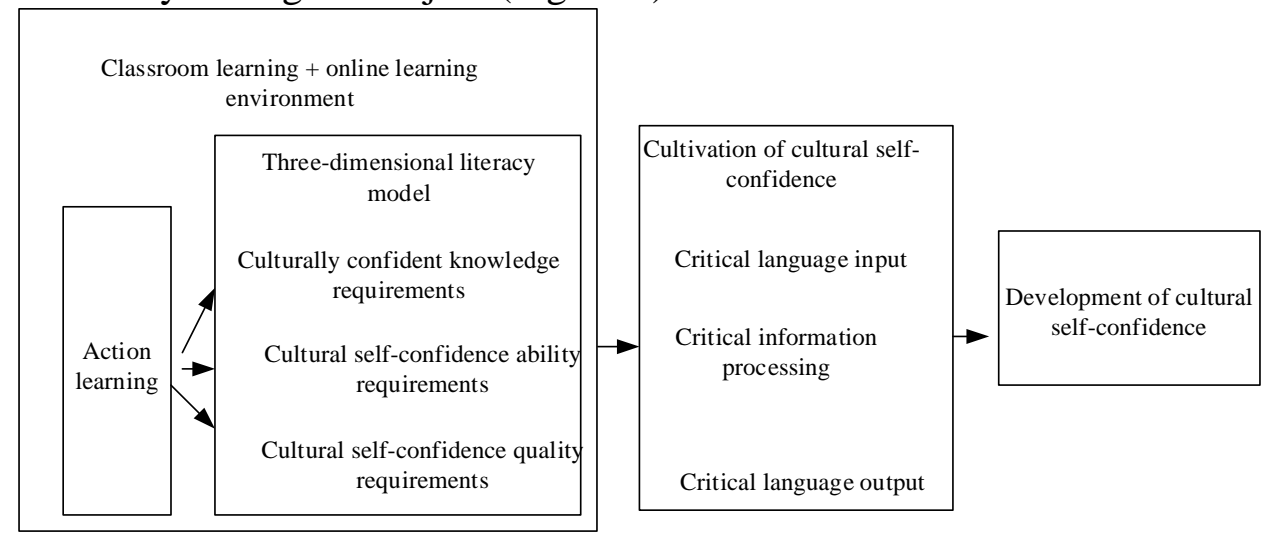

Figure 1. Theoretical framework for cultivating young people's cultural self-confidence.

The framework focuses on cultural self-confidence and “three-dimensional literacy model”, and 
creatively integrates action learning into each learning process of "three-dimensional literacy model" to achieve "learning in action" and "improving in action". Students can discover, analyze and solve problems in the process of cultivating cultural self-confidence and core literacy such as knowledge, ability and quality, and further enhance their cultural self-confidence.

To cultivate cultural self-confidence, English teaching should also break through the barriers of linguistic education and carry out speech education, that is, curriculum implementation should be based on language, transcend language, and go to culture. In view of the cultural interlanguage, this process can be driven by Chinese discourse, and it drives and optimizes language representation and cultural awareness around a series of traditional or contemporary cultural events, as shown in Figure 2.

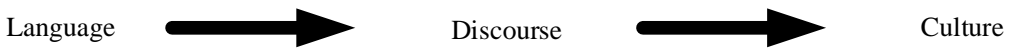

Figure 2. The relationship between language, discourse and culture.

That is to say, the English curriculum in the perspective of cultural self-confidence is a process in which teachers and students work together to create new educational experiences in specific teaching situations. In this process, the responsibility of the main body of the course, the promotion of the curriculum mechanism and the enrichment of the course media are critical.

Cultural confidence knowledge mainly refers to the content of the course "Introduction to Chinese Culture”, “Chinese Culture Research", "Chinese-Western Cultural Contrast”, and the Chinese cultural content introduced in the courses "Basic English", "Advanced English" and "English Reading".

Cultural self-confidence ability includes the use of English to express Chinese culture, communication strategies, intercultural communication, critical thinking, cultural identity, and cultural translation. In the specific teaching, teachers can organize novel and diverse activities to guide students to prepare corresponding teaching topics before class, use heuristic or task teaching method in classroom teaching, and build network-based learning community to develop activities after class; teachers need to encourage students to understand and memorize the expression of Chinese culture and introduce it in a variety of occasions, so that students can flexibly use discourse strategies to exercise social interaction skills, and it also help students to transfer the communication strategies learned in the classroom to the outside of the classroom and improve cross-cultural communication skills. At the same time, students need to treat cultural differences between the East and the West in a prudent and objective manner. Learning Chinese culture helps students to establish a correct national image awareness, improve their ability to maintain, disseminate and enhance their national image, and have a correct understanding and evaluation of the image of other countries.

Learning Chinese culture helps foreign language teachers and students to consolidate and improve their political consciousness and ideological quality, and it is conducive to creating a learning atmosphere that conforms to objective reality, harmonious Chinese and foreign cultures, enhances and spreads their own culture, and can establish a critical absorption of foreign culture and enrichment, enhance the style of study of their own culture, so that foreign language teaching can better serve the socialist construction, and cultivate a communicator who has both a sense of cultural mission and responsibility and can publicize the excellent culture of China. 


\subsection{Research methods}

The experiment tests and analyzes the teaching behavior of English teachers with the Teacher Teaching Behavior Questionnaire. The purpose is to find out the influence of teachers' behavior in the classroom on students' self-confidence in English learning, and then analyze. Therefore, further measures are taken to cultivate students' self-confidence. This questionnaire consists of 20 topics designed to understand the impact of English teachers' teaching behavior on students' self-confidence in English learning, such as teacher language, attitude towards students, understanding of individual differences among students, and positive education for students. This questionnaire is not signed.

\section{Results and discussion}

In order to ensure the validity and reliability of the survey, the questionnaire is completed within 10 minutes before the students take the class. Inform the respondents that the survey results are not related to the academic performance before the survey. This questionnaire is not signed. In this survey, 100 questionnaires are collected and the data are described and statistically analyzed. The following analysis and evaluation are based on the survey results:

Table 1. Interest in learning English.

\begin{tabular}{|c|c|c|c|c|c|}
\hline \multirow{5}{*}{$\begin{array}{l}\text { I don't like to take English } \\
\text { classes. }\end{array}$} & $\mathrm{a}$ & 35 & $70 \%$ & 36 & $72 \%$ \\
\hline & b & 8 & $16 \%$ & 6 & $12 \%$ \\
\hline & C & 5 & $10 \%$ & 5 & $10 \%$ \\
\hline & $\mathrm{d}$ & 2 & $4 \%$ & 1 & $2 \%$ \\
\hline & e & 0 & 0 & 2 & $4 \%$ \\
\hline \multirow{5}{*}{$\begin{array}{l}\text { I feel that English learning } \\
\text { is boring. }\end{array}$} & $\mathrm{a}$ & 30 & $60 \%$ & 35 & $70 \%$ \\
\hline & b & 13 & $26 \%$ & 11 & $22 \%$ \\
\hline & $\mathrm{C}$ & 4 & $8 \%$ & 1 & $2 \%$ \\
\hline & $\mathrm{d}$ & 2 & $4 \%$ & 2 & $4 \%$ \\
\hline & e & 1 & $2 \%$ & 1 & $2 \%$ \\
\hline \multirow{5}{*}{$\begin{array}{l}\text { I don't like to answer } \\
\text { questions or participate in } \\
\text { activities in class. }\end{array}$} & $\mathrm{a}$ & 22 & $44 \%$ & 29 & $58 \%$ \\
\hline & $\mathrm{b}$ & 11 & $22 \%$ & 7 & $14 \%$ \\
\hline & C & 11 & $22 \%$ & 12 & $24 \%$ \\
\hline & $\mathrm{d}$ & 2 & $4 \%$ & 1 & $2 \%$ \\
\hline & e & 4 & $8 \%$ & 1 & $2 \%$ \\
\hline
\end{tabular}

As shown in Table 1, 70\% of students like to take English classes, and class 2 is as high as $72 \%$; only 2\% of students feel that English learning is not interesting; when answering questions, most of them are active.

As shown in the table 2, the teacher's motivational language, comments on assignments, and evaluation of grades all have an impact on student self-confidence. Among them, 64\% of students in class 1 hope to have motivational language in the class, $56 \%$ in class 2, and the proportion of class 1 is greater than class 2. More than half of the students hope to get a good teacher's comments on their homework, which will encourage the enthusiasm of learning English. 
Table 2. Teacher's evaluation of students.

\begin{tabular}{|c|c|c|c|c|c|}
\hline \multirow{5}{*}{$\begin{array}{l}\text { Passive speech in the } \\
\text { classroom, the teacher's } \\
\text { frequent criticism makes } \\
\text { me feel no sense of } \\
\text { accomplishment. }\end{array}$} & $\mathrm{a}$ & 34 & $68 \%$ & 19 & $38 \%$ \\
\hline & b & 4 & $8 \%$ & 11 & $22 \%$ \\
\hline & C & 10 & $20 \%$ & 11 & $22 \%$ \\
\hline & $\mathrm{d}$ & 1 & $2 \%$ & 5 & $10 \%$ \\
\hline & e & 1 & $2 \%$ & 4 & $8 \%$ \\
\hline \multirow{5}{*}{$\begin{array}{l}\text { English classes are too } \\
\text { dull and too little } \\
\text { motivation. }\end{array}$} & $\mathrm{a}$ & 32 & $64 \%$ & 28 & $56 \%$ \\
\hline & b & 12 & $24 \%$ & 8 & $16 \%$ \\
\hline & C & 5 & $10 \%$ & 11 & $22 \%$ \\
\hline & $\mathrm{d}$ & 0 & 0 & 0 & 0 \\
\hline & e & 1 & $2 \%$ & 3 & $6 \%$ \\
\hline \multirow{5}{*}{$\begin{array}{l}\text { The teacher is too } \\
\text { concerned about the } \\
\text { mid-term and final grades. } \\
\text { I feel that learning English } \\
\text { is not interesting. }\end{array}$} & $\mathrm{a}$ & 27 & $54 \%$ & 28 & $56 \%$ \\
\hline & b & 12 & $24 \%$ & 13 & $26 \%$ \\
\hline & C & 6 & $12 \%$ & 3 & $6 \%$ \\
\hline & $\mathrm{d}$ & 0 & 0 & 2 & $4 \%$ \\
\hline & e & 5 & $10 \%$ & 4 & $8 \%$ \\
\hline \multirow{5}{*}{$\begin{array}{l}\text { The severe criticism of the } \\
\text { teacher will make me feel } \\
\text { resistant to English } \\
\text { learning. }\end{array}$} & $\mathrm{a}$ & 29 & $58 \%$ & 25 & $50 \%$ \\
\hline & b & 7 & $14 \%$ & 7 & $14 \%$ \\
\hline & C & 7 & $14 \%$ & 10 & $20 \%$ \\
\hline & $d$ & 4 & $8 \%$ & 4 & $8 \%$ \\
\hline & e & 3 & $6 \%$ & 4 & $8 \%$ \\
\hline \multirow{5}{*}{$\begin{array}{l}\text { Seeing the teacher's good } \\
\text { comments on my } \\
\text { homework will enhance } \\
\text { my enthusiasm for } \\
\text { learning a foreign } \\
\text { language. }\end{array}$} & $\mathrm{a}$ & 7 & $14 \%$ & 3 & $6 \%$ \\
\hline & b & 3 & $6 \%$ & 4 & $8 \%$ \\
\hline & C & 6 & $12 \%$ & 7 & $14 \%$ \\
\hline & d & 4 & $8 \%$ & 8 & $16 \%$ \\
\hline & e & 30 & $60 \%$ & 28 & $56 \%$ \\
\hline \multirow{5}{*}{$\begin{array}{l}\text { The questions answered in } \\
\text { the class are wrong, and } \\
\text { the teacher's criticism will } \\
\text { make me feel the pain of } \\
\text { failure, so I don't want to } \\
\text { learn English. }\end{array}$} & $\mathrm{a}$ & 34 & $68 \%$ & 35 & $70 \%$ \\
\hline & $\mathrm{b}$ & 9 & $18 \%$ & 5 & $10 \%$ \\
\hline & C & 4 & $8 \%$ & 5 & $10 \%$ \\
\hline & $\mathrm{d}$ & 1 & $2 \%$ & 2 & $4 \%$ \\
\hline & e & 2 & $4 \%$ & 3 & $6 \%$ \\
\hline
\end{tabular}

Table 3. Teacher's emotional education for students.

\begin{tabular}{cccccc}
\hline & $\mathrm{a}$ & 11 & $22 \%$ & 5 & $10 \%$ \\
\cline { 2 - 6 } Teachers can effectively & $\mathrm{b}$ & 8 & $16 \%$ & 7 & $14 \%$ \\
\cline { 2 - 6 } teach according to the & $\mathrm{c}$ & 18 & $36 \%$ & 12 & $24 \%$ \\
\cline { 2 - 6 } $\begin{array}{c}\text { psychological } \\
\text { characteristics of students. }\end{array}$ & $\mathrm{d}$ & 1 & $2 \%$ & 7 & $14 \%$ \\
\cline { 2 - 6 } & $\mathrm{e}$ & 12 & $24 \%$ & 19 & $38 \%$ \\
\hline Talking to me after class & $\mathrm{a}$ & 13 & $26 \%$ & 6 & $12 \%$ \\
\cline { 2 - 6 } will make me feel kind & $\mathrm{b}$ & 4 & $8 \%$ & 6 & $12 \%$ \\
\cline { 2 - 6 } $\begin{array}{c}\text { and will enhance my } \\
\text { motivation to learn } \\
\text { English. }\end{array}$ & $\mathrm{c}$ & 6 & $12 \%$ & 8 & $16 \%$ \\
\cline { 2 - 6 } & $\mathrm{d}$ & 4 & $8 \%$ & 7 & $14 \%$ \\
\hline
\end{tabular}

The survey shows that teachers can effectively teach students according to their psychological 
characteristics. $38 \%$ of students in class 2 think so. Talking with students after class makes students feel kind, and at the same time enhances their motivation to learn and enhance their self-confidence in learning.

Table 4. Teacher's teaching concept to students.

\begin{tabular}{|c|c|c|c|c|c|}
\hline \multirow{5}{*}{$\begin{array}{l}\text { The teacher did not use } \\
\text { the content of the teaching } \\
\text { materials reasonably and } \\
\text { did not explore the } \\
\text { novelty of the teaching } \\
\text { content. }\end{array}$} & $\mathrm{a}$ & 34 & $68 \%$ & 33 & $66 \%$ \\
\hline & b & 8 & $16 \%$ & 9 & $18 \%$ \\
\hline & C & 5 & $10 \%$ & 4 & $8 \%$ \\
\hline & $\mathrm{d}$ & 0 & 0 & 1 & $2 \%$ \\
\hline & e & 3 & $6 \%$ & 3 & $6 \%$ \\
\hline \multirow{6}{*}{$\begin{array}{l}\text { Teachers only pay } \\
\text { attention to the } \\
\text { interpretation of language } \\
\text { knowledge, regardless of } \\
\text { students' personal needs } \\
\text { and emotional changes } \\
\text { will reduce the confidence } \\
\text { in learning English. }\end{array}$} & $\mathrm{a}$ & 25 & $50 \%$ & 22 & $44 \%$ \\
\hline & $\mathrm{b}$ & 15 & $30 \%$ & 10 & $20 \%$ \\
\hline & C & 6 & $12 \%$ & 8 & $16 \%$ \\
\hline & $\mathrm{d}$ & 1 & $2 \%$ & 4 & $8 \%$ \\
\hline & e & 3 & $6 \%$ & 6 & $12 \%$ \\
\hline & $\mathrm{a}$ & 37 & $74 \%$ & 32 & $64 \%$ \\
\hline \multirow{4}{*}{$\begin{array}{l}\text { Our English classes are } \\
\text { often heavy and } \\
\text { depressed. }\end{array}$} & $\mathrm{b}$ & 6 & $12 \%$ & 8 & $16 \%$ \\
\hline & C & 5 & $10 \%$ & 3 & $6 \%$ \\
\hline & $\mathrm{d}$ & 1 & $2 \%$ & 3 & $6 \%$ \\
\hline & & 1 & $2 \%$ & 4 & $8 \%$ \\
\hline
\end{tabular}

The teacher's teaching concept is novel, focusing on the individual needs and emotional changes of students will enhance students' confidence in learning English. As shown in the table: 68\% of the students think that the teacher can use the teaching materials reasonably and discover the novelty of the content; $2 \%$ of students in class 1 think that the class is heavily depressed, and class 2 is $8 \%$. More than half of them think that the class is relaxed and happy. It can be concluded that the teacher's good teaching concept largely determines the self-confidence of students in learning English.

Table 5. Teacher's emotions towards students.

\begin{tabular}{cccccc} 
Teachers' negative & $\mathrm{a}$ & 23 & $46 \%$ & 23 & $46 \%$ \\
\cline { 2 - 6 } emotions will dampen my & $\mathrm{b}$ & 8 & $16 \%$ & 12 & $24 \%$ \\
\cline { 2 - 6 } enthusiasm for learning & $\mathrm{c}$ & 11 & $22 \%$ & 6 & $12 \%$ \\
\cline { 2 - 6 } English. & $\mathrm{d}$ & 0 & 0 & 5 & $10 \%$ \\
\cline { 2 - 6 } & $\mathrm{e}$ & 8 & $16 \%$ & 4 & $8 \%$
\end{tabular}

In addition, teachers' emotions also affect students' self-confidence in English learning. 46\% of them believe that teachers' negative emotions will dampen the enthusiasm of learning English, thus affecting self-confidence.

Generally speaking, under the perspective of cultural self-confidence, the English curriculum needs to be fully turned to promote the interaction between the language micro-course and the social curriculum, so that it is possible to truly carry out cross-cultural exchanges and promote mutual understanding of civilization. 


\subsection{Spread Chinese culture}

To cultivate cultural self-confidence, the English curriculum must first improve the teaching objectives. Looking back at history, the goal of the English curriculum is not static, but closely linked to the national development strategy. In the 30 years before the reform and opening up, China went to the world, and foreign languages have sufficient "legality" as tools. In the 30 years since the reform and opening up, especially since the beginning of the new century, as China has changed from a "native country" to an "international country", "cultural power" and "Chinese culture go global" have become major national strategies. In the face of new national and social needs, it is proposed to "enhance national language strength, disseminate Chinese culture, promote extensive exchanges with people of all countries, and enhance national soft power." This is not to deprive or weaken the mother tongue culture and civilization, but to supplement and strengthen the absent native language culture and civilization. It is a transformation from overcoming "Chinization" to promoting "Chinization" to help learners achieve the teaching goals of learning the world experience and the educational goals of spreading Chinese culture and implement the "all-person" cultivation goal of the curriculum.

\subsection{Encourage "Chinese English"}

As a companion to the globalization process, English has gradually developed into an international lingua franca, and it is impossible to change in a short time. The traditional monolingual mode of English gradually turned into a multi-modal and multicultural co-existing and blended compound paradigm, which became a new normal of the context of contemporary English use. In this context, the dissemination of national culture in English has become one of the important practical ways for Chinese culture to go out, that is, to characterize China's "unique things" in standardized English. As far as cultural cognition is concerned, on the one hand, Chinese English should express traditional Chinese culture, including academic thought, religion, education, literature, art, science and technology, architecture, history, language and so on. On the other hand, it is also necessary to project the basic national conditions of contemporary China. In order to cultivate cultural self-confidence, English courses should not only be based on the introduction of surface culture, but it should be appreciated by deep culture. Young people are active in thinking and easy to accept new things, but at the same time they lack certain "sublation ability". It is necessary to carry out Chinese-Western cultural contrast and dialogue.

\subsection{Developing Chinese discourse}

The generation of cultural self-confidence has its own rules, cultural cognition is the premise, cultural communication is the condition, and the mastery of cultural discourse is the key.

First of all, "teachers and students are courses." As a dual messenger of language and culture, English teachers must transcend "technical rationality", pursue "practical rationality" and "emancipate rationality" in the implementation of the curriculum, and strive to embody a solid English language heritage and profound Chinese cultural literacy. English teachers should help learners to improve their sense of subjectivity, optimize the content and form of speech, and clarify the social and cultural effects. On the other hand, as the main body of Chinese culture, there is also a huge subjective consciousness, initiative and creativity among learners, and through discourse guidance and discovery activities such as discovery, inquiry, and discussion, not only cultural cognition can be transmitted, but cultural identity can be expected.

Second, the activity produces meaning. Cultural self-confidence is essentially a kind of psychological experience. It is direct, lively and implicit. It needs to exert the learner's subjectivity, 
interaction and problem-solving ability through activities to gain a complete understanding of the world. Specifically, in the context of cultural self-confidence, classroom teaching advocates starting from the people and things in the life of the learner, combining a series of traditional or contemporary cultural events, through the production tasks that are true and in line with the learner's language level. It not only points to language output such as phonetics, vocabulary and grammar, but also implements verbal practice through mutual authentication and mutual interpretation to verify, contrast and appreciate the historical background and practical significance of different civilizations and their discourses, and through the activities to acquire potential values, norms and attitudes.

Third, the medium is literacy. In the era of mass media, education needs to cultivate people's media literacy, so that people have the ability to use the media and critical awareness of the media. In the context of cultural self-confidence, teaching materials should comprehensively include language, communication and cultural factors to promote true, two-way cross-cultural communication. Specifically, in addition to introducing foreign cultures, teaching should also promote local culture, and enhance the learners' understanding of different cultural discourses with the teaching resources of relevance, authenticity, applicability, time, and multimodality. Establish a cultural attitude of equality, tolerance, cooperation and mutual benefit. At the same time, in the information age, the boundaries between the first classroom and the second classroom are blurred. The three-dimensional teaching style of classroom + network is worth encouraging. Learners can conduct Chinese discourse discussions centered on the classroom, and then use the Internet as a platform to assist Chinese discourse reflection and promote the dual improvement of language skills and cultural self-confidence.

\subsection{Identify China's value}

Cultural self-confidence is cognition and attitude. Whether the English curriculum achieves the expected curriculum objectives in the perspective of cultural self-confidence, it mainly considers the cultural consciousness, cultural introspection and cultural self-confidence change before and after the learner's curriculum: that is, culturally conscious, whether the curriculum promotes learners' multicultural awareness and local value perception; in terms of cultural introspection, does the curriculum promote learners' cultural criticism and dialectical attitudes; in terms of cultural self-confidence, does the curriculum promote the new dimension of learner's subject identity, local value identity and spiritual life quality. Culture is an ideographic practice; it is also a description of a particular way of life. Through the examination of the learner's Chinese English output ability and the practice of Chinese discourse, the English curriculum in the perspective of cultural self-confidence is ultimately aimed at realizing that "all the functions of thought are the habit of generating action".

\section{Conclusion}

Cultural self-confidence is a major social and cultural issue in contemporary China. Cultural self-confidence takes value as the core and discourse as the intermediary. Taking language and discourse as a medium, constructing Chinese cultural discourse will become an important social practice in the current and future for a long period of time. In the cultivation of cultural self-confidence, subject research is particularly important and more realistic. In order to nurture the cultural confidence of young people, they should be closely linked to their study and life. The depth of the course must be culture. The English course is one of the main channels for the exchange and communication between Chinese and Western cultures. It should be a three-way interaction of ideology, communication and thinking. Through the reflection of different cultures and the fusion 
of horizons, Chinese culture will be sent to the other shore. English courses need to highlight social orientation, supplement the content of mother tongue culture, carry out cultural discourse practice, promote value identification, and promote learners to tell Chinese stories and concise Chinese discourse and China's value, finally it will become a new generation of cultural self-awareness and cultural self-confidence.

\section{References}

[1] Tucker, L. A., George, G., Reardon, C., \& Panday, S. (2016). 'learning the basics': young people’s engagement with sexuality education at secondary schools. Sex Education, 16(4), 337-352. doi.org/10.4236/ce.2016.711162

[2] Ellis, V., Maguire, M., Trippestad, T. A., Liu, Y., Yang, X., \& Zeichner, K. (2016). Teaching other people's children, elsewhere, for a while: the rhetoric of a travelling educational reform. Journal of Education Policy, 31(1), 60-80. doi.org/10.5897/err2016.3003

[3] O'Shea, S. (2016). Avoiding the manufacture of 'sameness': first-in-family students, cultural capital and the higher education environment. Higher Education, 72(1), 59-78. doi.org/10.1353/jhe.2016.0011

[4] Hayes, A. L., \& Mansour, N. (2016). Confidence in the knowledge base of english language learners studying science: using agency to compensate for the lack of adequate linguistic identity. Research in Science Education, 47(2), 1-19. doi.org/10.5861/ijrsll.2016.1544

[5] Forbes, A., \& Skamp, K. (2016). Secondary science teachers' and students' involvement in a primary school community of science practice: how it changed their practices and interest in science. Research in Science Education, 46(1), 91-112. doi.org/10.5455/medscience.2016.05.84556

[6] Peng, Y., Chahine, S., \& Husein, M. (2017). Improving learning and confidence through small group, structured otoscopy teaching: a prospective interventional study. Journal of Otolaryngology - Head \& Neck Surgery, 46(1), 68. doi.org/10.1016/j.cptl.2016.05.004

[7] Sewell, J. L., Boscardin, C. K., Young, J. Q., Ten, C. O., \& O'Sullivan, P. S. (2017). Learner, patient, and supervisor features are associated with different types of cognitive load during procedural skills training: implications for teaching and instructional design. Academic Medicine, 92(11), doi.org/10.1016/j.pec.2017.02.006

[8] Bartlett, L., Mendenhall, M., \& Ghaffar-Kucher, A. (2017). Culture in acculturation: Refugee youth's schooling experiences in international schools in New York City. International Journal of Intercultural Relations, 60, $109-119$. doi.org/10.1016/j.ijintrel.2017.04.005

[9] Thomas, E. E., \& Warren, C. A. (2017). Making it relevant: How a black male teacher sustained professional relationships through culturally responsive discourse. Race Ethnicity and Education, 20(1), 87-100. doi.org/10.17265/2161-6248/2017.02.003

[10] Warren, C. A. (2018). Empathy, teacher dispositions, and preparation for culturally responsive pedagogy. Journal of Teacher Education, 69(2), 169-183. doi.org/10.1016/j.tate.2018.06.013

[11] Gutiérrez, V., Larson, R. W., Raffaelli, M., Fernandez, M., \& Guzman, S. (2017). How Staff of Youth Programs Respond to Culture-Related Incidents: Nonengagement Versus Going "Full-Right-In". Journal of Adolescent Research, 32(1), 64-93. doi.org/10.1080/19361653.2017.1324342

[12] Serpell, R. (2017). How the study of cognitive growth can benefit from a cultural lens. Perspectives on Psychological Science, 12(5), 889-899. doi.org/10.1017/hor.2017.53 